\title{
A Survival Guide: The Student Success Handbook for Learners in Project Based Science Environments
}

\author{
Jackie Gray, Harriett Groves, and Janet Kolodner \\ Georgia Institute of Technology, College of Computing, Atlanta, GA 30332 \\ grayj@cc.gatech.edu, harriett@cc.gatech.edu,jlk@cc.gatech.edu
}

\begin{abstract}
Encouraging middle school students to practice reflection, self assessment, and recognition that skills for life-long learning develop across time are the goals for our handbook.
\end{abstract}

Keywords: assessment, life-long learning, middle school, reflection

How do you help middle school students learn about science and design and in the process help them develop their skills as self-regulated learners? In Learning by Design classrooms, we have observed students and teachers trying to achieve this. We know from research in the learning sciences that for deep learning to occur, students need to grapple with ill- defined problems and by doing so, motivate their need to know science content. On the way to solving challenging design problems, students stumble over the need to hone their individual skills, to work as teams, and to acquire new knowledge. These are no easy feats for middle school students and their teachers! In our observations and curriculum implementations we have learned much about what seems difficult for students. We've developed a Student Success Handbook to make the terrain more manageable. The conceptual rationale for the book (self assessment, scaffolding) shares Vygotsky's view that learning is internalized after experiences are socially and externally supported (Vygotsky, 1978) and Stipek's work on self assessment (Stipek, Recchia, and McClintic , 1992). We take the much-argued position that students are best prepared to exhibit their competence when they know what will be used to judge their performance (O'Sullivan, 1997, personal communication).

Our book contains four chapters to date. In the first chapter, we introduce students to Learning by Design (Kolodner, et al, 1998) and the types of learning they will encounter in such environments (students in project based learning and other constructivist environments are potential audiences for later versions of the book). The major themes of the book are: developing skills across time, individual differences in learning, learning from collaboration, noticing skills, learning from cases (Kolodner, 1997; Dagher, 1997), expertise, design and reflection.

The second chapter provides a chance for students to understand multiple ways of knowing, diversity and self assessment We want the students to think about who they are as learners and what their natural talents and interests are and to realize that with practice they can develop new strengths. We also want then to think about how they learn and how they can contribute in a collaborative group. Short narratives of middle-school aged students were developed using Gardner's theory of multiple intelligences (Gardner, 1985) to portray the seven ways of knowing he describes. These narratives are used to introduce self-assessment checklists that allow students to assess their own unique learning styles. Chapter three focuses on learning new skills; chapter four focuses on collaboration; chapter five on design processes and chapter six on science processes. We have drafts of chapters 1 , 2,3 , and 5 .

A major theme of the book is encouraging learners to notice. To aid in the development of noticing skills, the book contains several visual and narrative contrastive sets. Contrastive sets are powerful in helping learners notice details and important aspects of an object or textual passage that they might otherwise miss (Bransford, Vye \& Sherwood, 1989). The visual sets precede textual sets and set up a continuum for the cases to follow. In the 
chapter on noticing skill, students are exposed to the notion of intelligent novices and the role of scaffolding that can be provided by experts.

The collaboration chapter helps to make the students understand the value and unique affordances of moving from cooperation to true collaboration. At the beginning of the design chapter, two designers describe the actions they took and the decisions they made in the process of designing two Atlanta buildings (a contrastive set of cases on design). After the students have a chance to think about the process of design, we identify and describe some of the actions taken in the design process. Throughout each of the chapters, we have students pause, reflect and assess themselves on various aspects of each of the themes.

What do we know about teens from our curriculum development efforts and the focus groups on our book? They like humor in the writing. Designing a birdcage caught their imagination and provided humor from their perspective. They also said they would like to read other designer's accounts of the design process. One suggests he would like to know the actions and decisions in the design of the Eiffel tower. We are collecting real design cases to address this natural curiosity! For example, a textile engineer has designed new toe shoes for ballet that will last for more performances than the current versions. Our goal is to provide students with an interesting survival guide to learning to become self-directed in project-based environments. Making the standards by which these young people will be evaluated transparent to them can serve to articulate the value we hold for them as learners.

\section{References}

Bransford, J. D.. Franks, J. J., Vye, N. J., and Sherwood, R. D. (1989). New approaches to instruction: Because wisdom can't be told. In S. Vosniadou and A. Ortony, (Eds.). Similarity and analogical reasoning (369412). New York: Cambridge University Press.

Dagher, Z. R. (1997). The case for analogies in teaching science for understanding. In J. J. J. Mintzes, H. H. Wandersee, and J. D. Novak (Eds.). (1997). Teaching Science for Understanding: A human constructivist view. (195-211). NY: Academic Press

Gardner, H., (1985). Frames of mind: The theory of multiple intelligences. New York: Basic Books.

Kolodner, J. L. (1997). Educational implications of analogy: A view from case-Based Reasoning. American Psychologist, 52, 35-44.

Stipek, D., Recchia, S., and McClintic, S. (1992). Self-evaluation in young children. Monographs of the Society for Research in Child Development, Vol. 57, No. 1.

Vygotsky, L. S. (1978). Mind in society: The development of higher psychological processes. Cambridge, Mass.: Harvard University Press.

\section{Acknowledements}

This project is supported in part, by the BellSouth Foundation, the National Science Foundation, the McDonnell Foundation, and the Woodruff Foundation. Opinions expressed are those of the authors and not necessarily those of either foundation. 